\title{
ХАРАКТЕРИСТИКА БИТУМОИДОВ ГОРЮЧЕГО СЛАНЦА ЧАГАНСКОГО МЕСТОРОЖДЕНИЯ ОРЕНБУРГСКОЙ ОБЛАСТИ
}

Исследование чаганского горючего сланца, расположенного на Южном Урале, началось лишь в последние годы. В литературе этот сланец не описан *.

Сланценосная толща чаганского месторождения представляет собой три слоя битуминозных глин, включающих пласты горючих сланцев, разделенных известковистыми глинами с прослоями известняков. Мощность сланценосной толщи достигает $30 \mathrm{~m}$, мощность пластов и пропластков горючих сланцев. колеблется от нескольких сантиметров до 3,5 м. Глубина залегания кровли сланценосной толщи составляет от 0 на севере до $300 \mu$ на юге. Лучшие по качеству - верхний пласт (толщина 0,9-1,3 $\mathrm{M}$, теплотворная способность $3500-4600$ ккал/кг) и нижний $(1-3 \mu, 2100-3000 \kappa \kappa a \Omega / \kappa 2)$. Ориентировочные запасы сланца на месторождении составляют 1 млрд. т. Доставленная для исследования проба отобрана из верхнего пласта. По внешнему виду чаганский сланец желтовато-серого цвета. Из вертикального к пласту разреза видно, что он осаждался тонкими слоями. Сланец представлен темно-серыми и зеленовато-бурыми глинистыми породами, богатыми органическим веществом (ОВ). Структура горючего сланца пелитоморфна. На глинистую массу приходится до $50 \%$ общего объема породы, она представлена в основном группами гидрослюд (гидромусковит и т. д.) и монтмориллонита. Текстура горючего сланца слоистая, наблюдается чередование обогащенных ОВ более темных слоев с более светлыми. Кластогенного материала, представленного в основном кварцем, не более $2-5 \%$. Порода содержит большое количество детрита морского происхождения, отличающегося хорошей сохранностью. Остальные $50 \%$ общего объема породы приходятся на ОВ, представленное бесструктурным гумусово-сапропелитовым веществом от коричневого до желто-коричневого цвета (сорбомикстинит).

Из измельченного сланца экстракцией хлороформом был выделен битумоид А, а после обработки $10 \%$-ной хлористоводородной кислотой - битумоид С (смесью метанола и бензола в отношении $1: 3$ ). Аналитические данные об исходном сланце, предварительно обработанном кислотой и затем дебитуминизированном, представлены в табл. 1, так же, как и данные о кашпирском сланце, близком чаганскому по географическому расположению, возрасту и химическому составу [']. Чаганский сланец обогащен ОВ $(56,7 \%)$ и отличается также высоким содержанием серы, которая находится в основном в структуре ОВ. Здесь необходимо отметить, что сланец не имеет постоянного состава:

* Пробу для исследования и ее геологическую характеристику представила Нежинская геолого-гидрогеологическая экспедиция Оренбургской области. 
Таблица 1

Характеристика исходного и дебитуминизированного сланца, вес. \%

\begin{tabular}{l|r|r|r|r}
\hline Показатели & $\begin{array}{c}\text { Исход- } \\
\text { ный }\end{array}$ & $\begin{array}{c}\text { После } \\
\text { обработ- } \\
\text { ки НСl }\end{array}$ & $\begin{array}{c}\text { Дебиту: } \\
\text { минизи- } \\
\text { рованный }\end{array}$ & $\begin{array}{c}\text { Кашпир- } \\
\text { ский } \\
{\left[{ }^{1}\right]}\end{array}$ \\
\hline Влага аналитическая & 2,9 & 1,2 & 3,8 & 6,7 \\
Зола прокаливания & 35,7 & 16,3 & 17,6 & 46,9 \\
Минеральная углекислота & 7,6 & 0 & 0 & 17,2 \\
Oрганнческое вещество & 56,7 & 83,7 & 82,4 & 35,9 \\
Сера общая, & 8,3 & 11,1 & 11,3 & 6,4 \\
в том числе: & 0,3 & 0 & 0 & - \\
элементарная & 0,1 & 0 & 0 & - \\
сульфатная & 1,9 & 3,8 & 3,9 & - \\
пиритная & 6,0 & 7,3 & 7,4 & - \\
органическая & & 62,5 & 64,5 & 65,1 \\
Элементный состав органического вещества: & & 8,2 & 7,8 & 7,7 \\
C & & 1,0 & 0,9 & 0,9 \\
H & & 8,7 & 9,0 & 11,7 \\
N & & 19,6 & 17,3 & 14,6 \\
S & & 1,6 & 1,4 & 1,4 \\
O & & &
\end{tabular}

Таблица 2

Выход и состав битумоидов, вес. \%

\begin{tabular}{|c|c|c|}
\hline Показатели & A & C \\
\hline \multicolumn{3}{|l|}{$\begin{array}{l}\text { Выход от OB } \\
\text { Элементный состав: }\end{array}$} \\
\hline Элементный состав: & 68,8 & 57.5 \\
\hline $\mathrm{H}$ & $\begin{array}{r}00,0 \\
9,1\end{array}$ & 8,1 \\
\hline $\mathrm{N}$ & 0,5 & 1,1 \\
\hline $\mathrm{S}_{\text {органическая }}$ & 7,2 & 1,6 \\
\hline $\begin{array}{l}\text { Sэлементарная } \\
\mathrm{O}\end{array}$ & 14.4 & $\begin{array}{r}6,4 \\
316\end{array}$ \\
\hline \multicolumn{3}{|l|}{ Групповой состав: } \\
\hline нейтральный битумоид & 40,7 & 3,4 \\
\hline карбоновые кислоты & 39,6 & 44,7 \\
\hline высокомолекулярные кислоты & 19,7 & 51,9 \\
\hline \multicolumn{3}{|l|}{ Состав нейтрального битумонда: } \\
\hline парафины & 7,9 & - \\
\hline алкилбензолы & 4,6 & - \\
\hline полициклические ароматические соединения & 5,4 & \\
\hline малополярные гетероатомные соединения & 20,8 & - \\
\hline сильнополярные гетероатомные соединения & 61,3 & - \\
\hline \multicolumn{3}{|l|}{ Состав карбоновых кислот: } \\
\hline монокарбоновые & 19,7 & 8,6 \\
\hline дикарбоновые & 23,7 & 14,5 \\
\hline поликарбоновые & 56,6 & 76,9 \\
\hline
\end{tabular}

в двух пробах, проанализированных в Институте сланцев Миннефтепрома СССР, содержание ОВ равнялось. 35,1 и $44,3 \%$, количество пиритной серы превышало количество органической.

В отличие от эстонских диктионемовых сланцев, близких по своему составу к чаганскому, последний легко обогащается OB при обработке кислотой. Содержащаяся в битумоидах элементарная сера была выделена с помощью медных стружек, а кислотные составляющие - омылением спиртовой щелочью. Нейтральный битумоид и кислоты были 


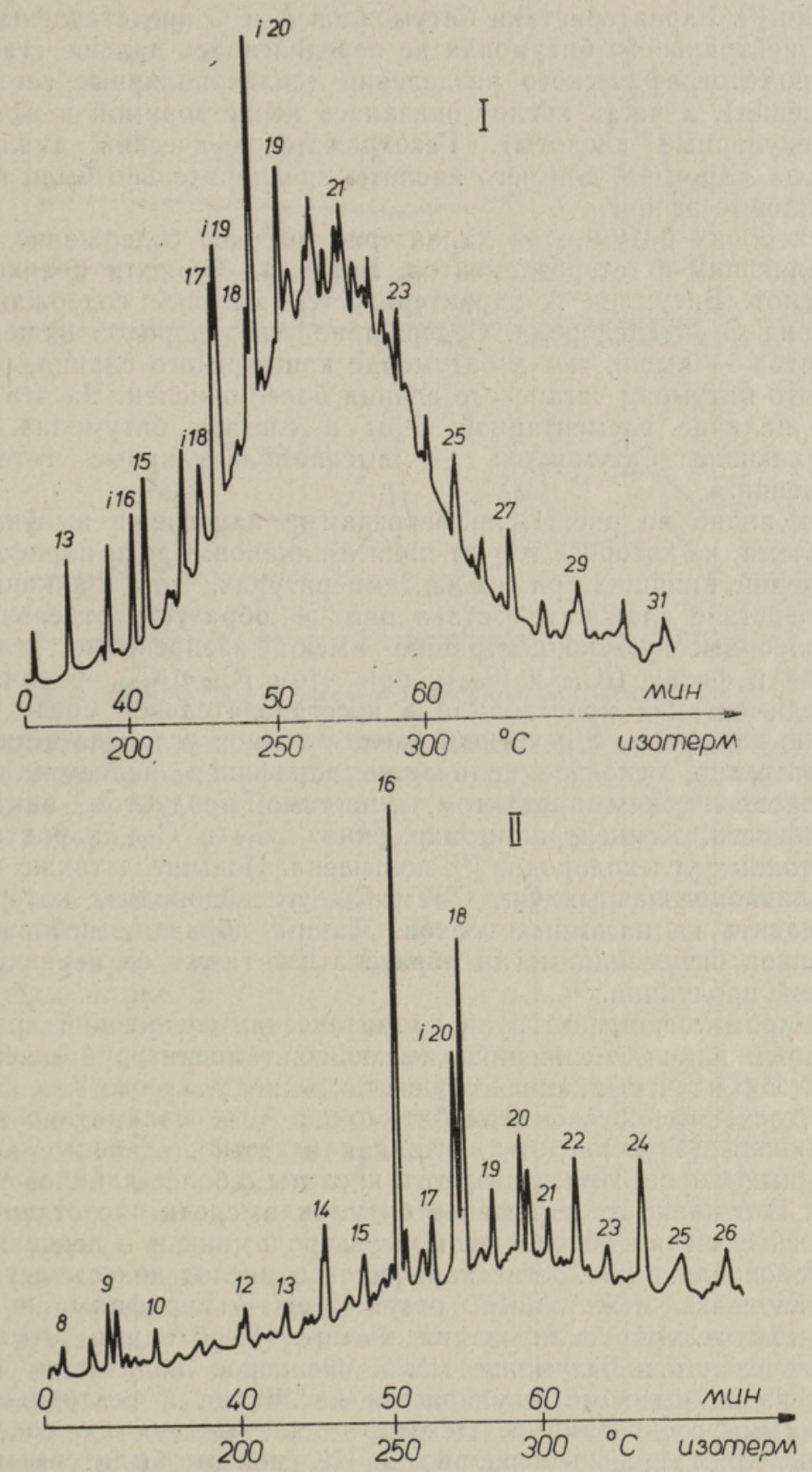

Рис. 1. Хроматограммы парафинов $(I)$ и метиловых эфиров монокарбоновых кислот (II) битумоида А. Номера означают количество углеродных атомов в соединениях. $i 16-i 20-$ изопреноиды. Колонка 3,6 м $\times 3$ мм. $7 \%$ Е 301 на целите 545 $(0,125-0,16$ мм $)$.

разделены на группы способом препаративной тонкослойной хроматографии, индивидуальный состав групп был определен газохроматогра- 
фически [ ${ }^{2}$. Характеристики битумоидов А и С представлены в табл. 2. Часть нейтрального битумоида не передвигалась дальше стартовой линии хроматографического разделения (сильнополярные гетероатомные соединения), а часть кислот оказалась нерастворимой в эфире (высокомолекулярные кислоты). Газохроматографический анализ проводился на «Хром-4», для чего кислоты предварительно были переведены в метиловые эфиры.

Для обоих битумоидов характерно высокое содержание кислотных составляющих и гетероэлементов. Битумоид С почти целиком состоит из кислот. Битумоид А характеризуется высоким содержаниөм серы, битумоид C - кислорода. Содержание углеводородов ниже, а гетероэлементов - выше, чем в битумоиде кашпирского сланца, откуда следует, что битумоид чаганского сланца более окислен. На это указывает также наличие элементарной серы в составе битумонда. Основные составляющие битумондов - высокомолекулярные гетероатомные соединения.

Как видно по рис. 1, хроматограмма парафинов выпуклая, имеет вид шлема, из которого торчат пики н-алканов. Среди парафинов много соединений, кипящих при тех же температурах, что и $\mathcal{H}$-алканы $\mathrm{C}_{17}-\mathrm{C}_{27}$, но вследствие сложного состава они не образуют .отдельных пиков. Наиболее высокую концентрацию имеют изопреновые углеводороды пристан и фитан $\left(i \mathrm{C}_{19}\right.$ и $\left.i \mathrm{C}_{20}\right)$, при этом $i \mathrm{C}_{19}<i \mathrm{C}_{20}$ - признак того, что седиментация происходила в восстановительной среде [3]. Преобладание парафинов с нечетным числом атомов углерода незначительно, следовательно, основное количество парафинов является не первичным биологическим продуктом, а видимо, продуктом бактериальной деятельности. Концентрация парафинов $\mathrm{C}_{17}$ и $\mathrm{C}_{19}$, характерных для планктонных углеводородов [ $\left.{ }^{4}\right]$, повышена. Повышена также концентрация длинноцепочечных $\mathrm{C}_{25}, \mathrm{C}_{27}$ и $\mathrm{C}_{29}$ углеводородов, которые могут происходить из наземных восков. Таким образом, небольшая часть парафинов битумонда могла образоваться также из первичной биологической продукции.

На хроматограммах групп ароматических соединений присутствуют отдельные пики соединений, имеющих температуру кипения выше $200^{\circ} \mathrm{C}$. Их идентификацию осуществить не удалось. Как показывает рис, 1, основные компоненты битумоида A - пальмитиновая $\left(\mathrm{C}_{16}\right)$ и стеариновая $\left(\mathrm{C}_{18}\right)$ кислоты. Это, как известно, основные компоненты природных жиров. Присутствуют и кислоты с более длинной углеродной цепью. В отличие от парафинов битумоида, среди кислот преобладают гомологи с четным числом атомов углерода, как и в первичной биологической продукции. Состав парафинов и кислот показывает, что генетическая связь между ними отсутствует - парафины не являются продуктом декарбоксилирования кислот. Необходимо отметить, что жирных кислот, в битумоиде мало. Основное количество битумоида представлено высокомолекулярными кислотами и нейтральными гетероатомными соединениями. Некоторые данные об их составе дают спектры, представленные на рис. 2. ИК-спектры были сняты на аппарате UR-20, ${ }^{1}$ Н-ЯMP-спектры на аппарате «Tesla BS-487». В ИК-спектре отдельные места поглощения недостаточно четкие, что свидетельствует о сложном строении исследуемого вещества. В спектрах биту моидов более четкие пики отвечают волновым числам $1380 ; 1460-1480$; 2860-2880: $2930-2960 \mathrm{~cm}^{-1}$, принадлежащим группам $\mathrm{CH}_{3}-$ и $-\mathrm{CH}_{2}$ - , равно как и волновым числам $1715-1750$ и $3200-3500 \mathrm{~cm}^{-1}$, что указывает на наличие в битумоиде карбонильных и гидроксильных групп. По данным 'Н-ЯМР-спектра, оба битумоида содержат 


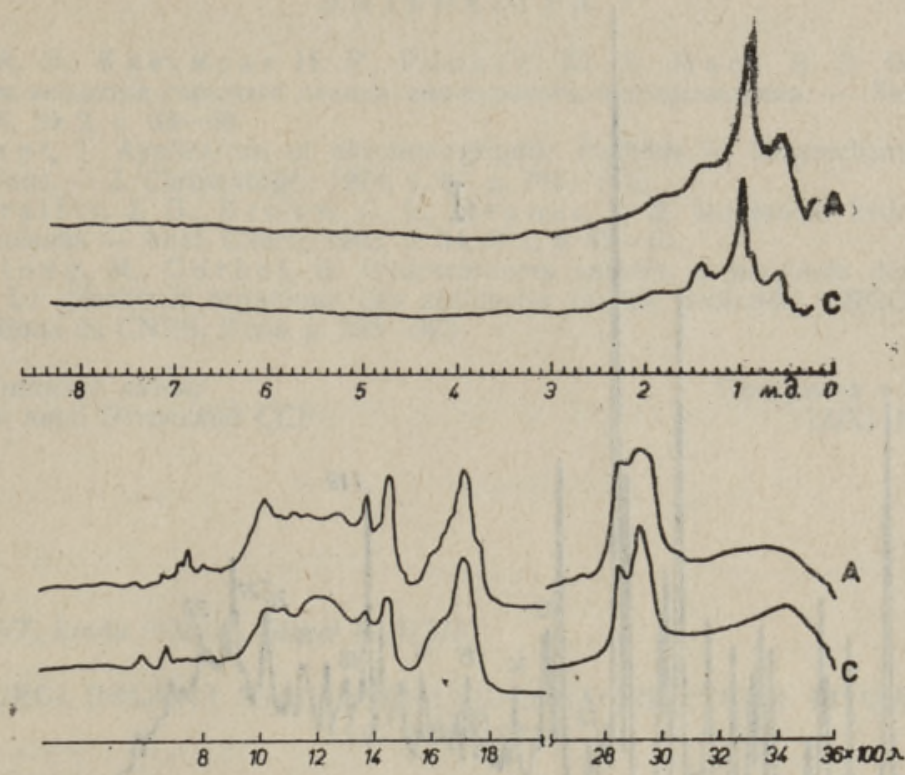

Рнс. 2. ${ }^{1}$ Н-ЯМР- и НК-спектры суммарных битумондов А и С.

много неразветвленных углеродных цепей $(1,2$ м.д.), значительна также доля водорода в разветвленных структурах и алифатических циклах $(1,3-2,3$ м. д.). Присутствует и небольшое количество ароматического водорода $(6,3-8,0$ м. б.), которого в малосернистых сланцах нет.

Некоторые данные об алифатических структурах высокомолекулярной части битумоида дает пиролиз. Пиролиз проводился в стеклянной трубке при температуре $450^{\circ}$. Хроматограммы жидких пиролизатов представлены на рис. 3 .

Пиролизат нейтральных сильнополярных гетероатомных соединений имеет сложный состав. В начале хроматограммы много пиков, которые, по-видимому, принадлежат сернистым соединениям. Присутствуют также длинные углеродные цепи, содержащие до 24 атомов углерода, но их доля невелика. Состав пиролизата высокомолекулярных кислот проще: преобладают нормальные углеводородные структуры. новые структуры высокомолекулярной части жирных кислот и парафинов битумоида никакого сходства между собой не имеют.

Чаганский горючий сланец отличается от других высокосернистых горючих сланцев высоким содержанием ОВ (35-57\%). Следует учесть, что сера вступила в структуру ОВ на первых стадиях литификации и она сульфатного происхождения. Для восстановления сульфатов бактерии расходовали часть ОВ седимента, благодаря чему концентрация OB в исходном отложении была еще выше. Деятельность сульфатвосстанавливающих бактерий сказывается также и на составе битумоида, который содержит в этом случае больше гетероэлементов (более окислен), чем находящиеся по соседству кашпирские сланцы, хотя последние также высокосернистые и юрского возраста. Возможно, что часть кислорода сланцев происходит из сульфатов. Ввиду того, что бактерии в первую очередь расходуют $н$-углеводородные структуры, в битумоиде осталось мало парафинов и в них повысилась концентрация изопреновых углеводородов. Главные структурные элементы ОВ всех горючих сланцев - 


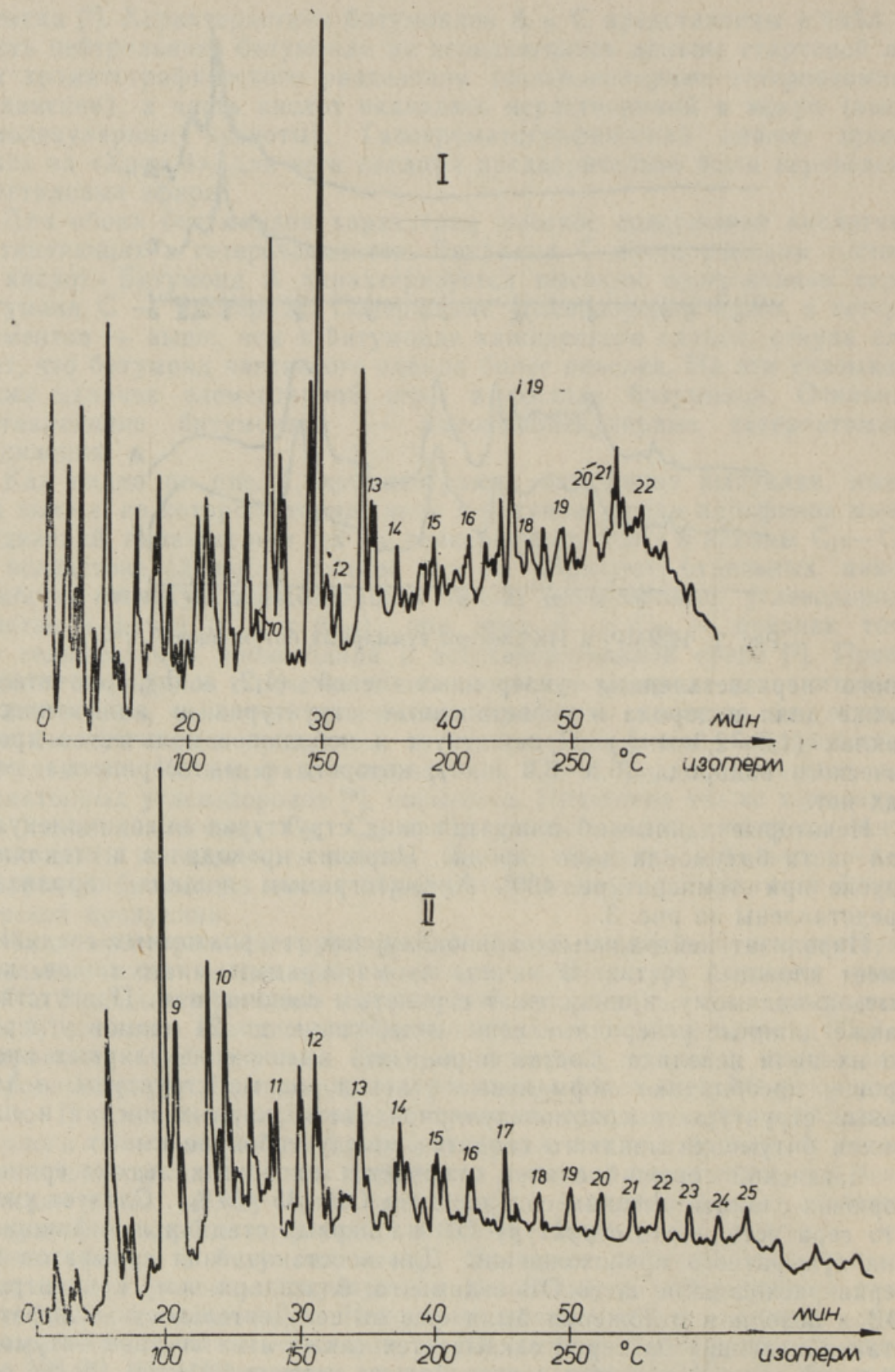

Рис. 3. Хроматограммы пиролизатов нейтральных сильнополярных гетероатомных соединений $(I)$ и высокомолекулярных кислот $(I I)$. Обозначения и условия хроматографирования - рис. 1.

чем в малосернистых сланцах. Источники образования ОВ битумоида чаганского сланца различны, но основное его количество ресинтезировано бактериями. 
ЛИТЕРА Т У РА

1. Уров К. Э., Клесмент И. Р., Риккен Ю. Т., Мяги Э. Э. Об органическом веществе горючего сланца кашпирского месторождения. - Хим. тв. топл., 1976, № 2, c. 63-69.

2. Klesment, I. Application of chromatographic methods in biogeochemical investigations. - J. Chromatogr., 1974, v. 91, p. 705-713.

3. B e ndora it is, J. G., B r ow n, C. L., H e p n e r, L. S. Isoprenoid hydrocarbons in petroleum. - Anal. Chem., 1962, v. 34, N 1, p. 49-53.

4. D a stillu ng, M., C o r bet, B. Hydrocarbures saturés et insaturés des sédiments. In: La géochimie organique des sédiments marins profonds. ORGON II, 1975, Editions du CNRS, Paris, p. 293-323.

Институт химии

Академии наук Эстонской ССР
Поступила в редакцию

$11 / \mathrm{XI} 1980$

\section{KLESMENT, Linda POBUL, Maret KUUSIK}

\section{ORENBURGI OBLASTI TSAGANSKI LEIUKOHA POLEVKIVI BITUMOIDIDE ISELOOMUSTUS}

\section{$K=A$}

Uuritud pōlevkivi orgáaniline aine sisaldab A- ja C-bitumoide vastavalt 1,1 ja $0,8 \%$. Bitumoidides on palju suure molekulmassiga ühendeid, seejuures on väävliühendid kontsentreerunud A-bitumoidi ja hapnikuühendid C-bitumoidi. On esitatud parafiinide ja hapete koostis. Võib konstateerida põlevkivi lähteaine tugevat bakteriaalset töötlust.

\section{KLESMENT, Linda POBUL, Maret KUUSIK}

\section{CHARACTERIZATION OF BITUMEN OF THE TSHAGANSK OIL SHALE (ORENBURG REGION)}

Organic matter content in bitumens $\mathrm{A}$ and $\mathrm{B}$ is 1.1 and $0.8 \%$, respectively. The bitumens are rich in compounds of a high molecular weight. The concentration of sulphur compounds is high in bitumoid A, that of oxygen compounds in bitumoid B. The paraffin and acid composition is given. The source material of oil shale is strongly bacteria-treated. 